\title{
إدارة الموارد الأسرية لأم الطفل المتوحد \\ وعلاقتها ببعض المتغيرات الاجتهاعية والاقتصادية "
}

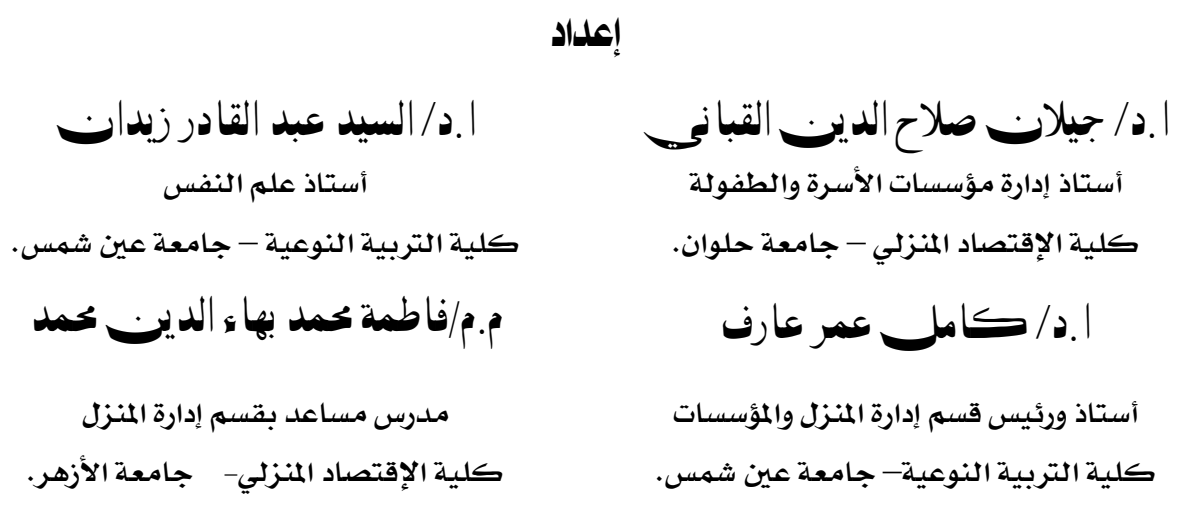

مجلة بحوث التربية النوعية ـ جامعة المنصورة

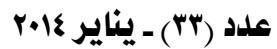

بحث مستل من رسالة دكتوراه 


\title{
وعلاقتها ببعض المتغيرات الاجتهماعية والاقتصادية
}

إعداد

\author{
ا ـد/السيد عبد القادرزيدازن \\ $* * * *$ \\ ק.م/فاطمةتحمد بهاء الدبزمحمد
}

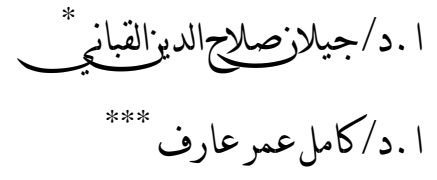

الإقدمة والمشكلة البحثية:

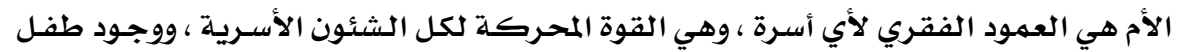

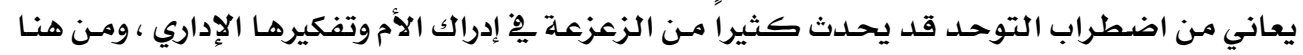

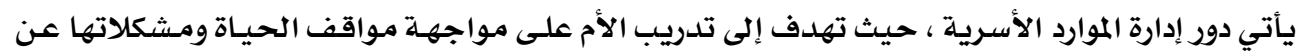

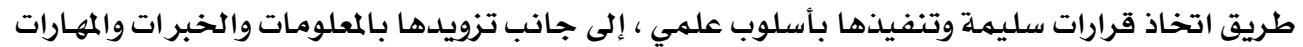

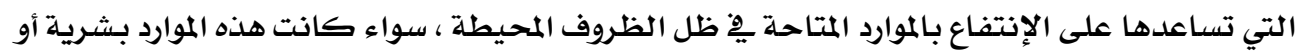

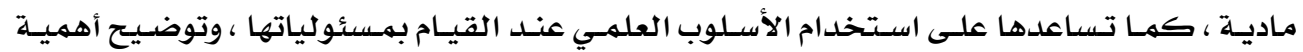

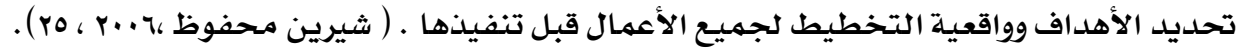

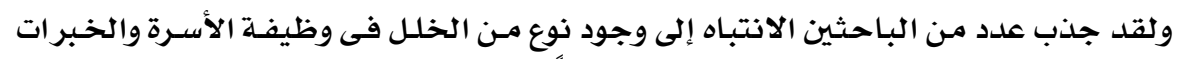

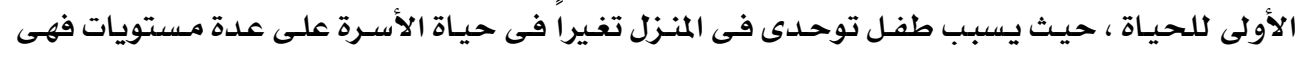

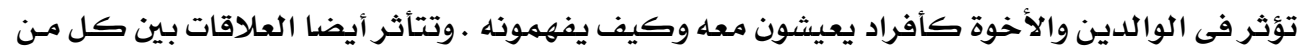

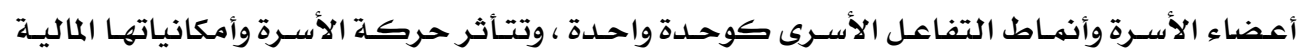

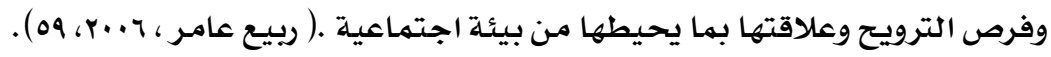

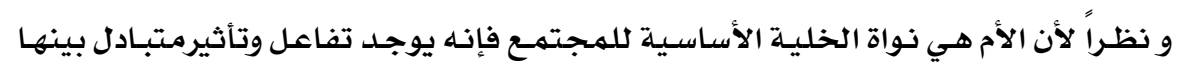

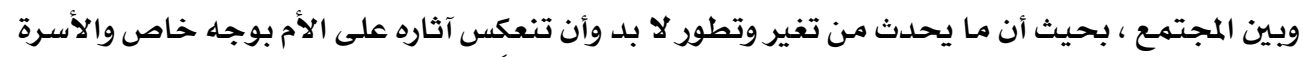

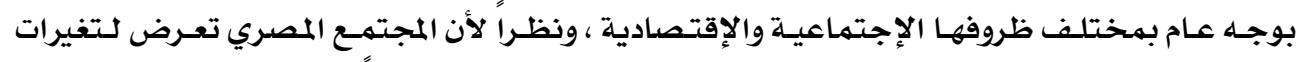

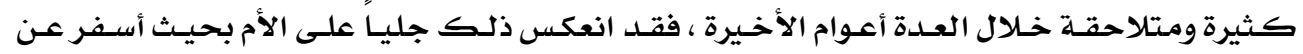

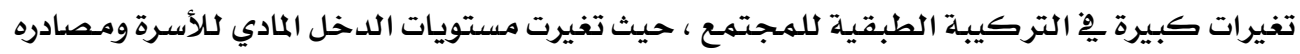

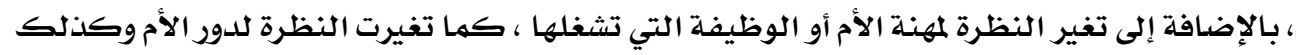

" أستاذ إدارة مؤسسات الأسرة والطفولة - كلية الإقتصاد المنزلي - جامعة حلوان

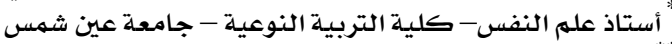

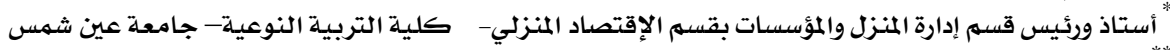

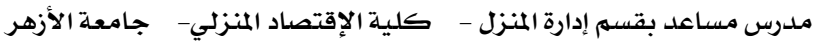




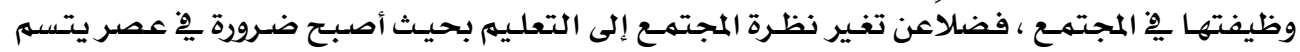

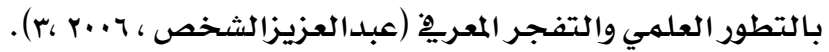

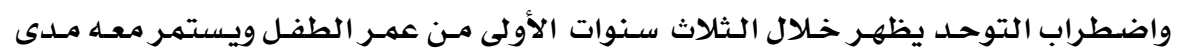

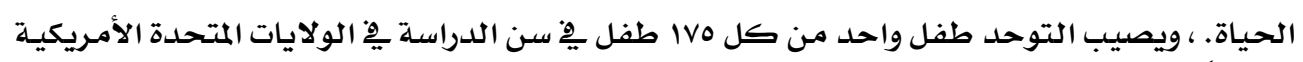

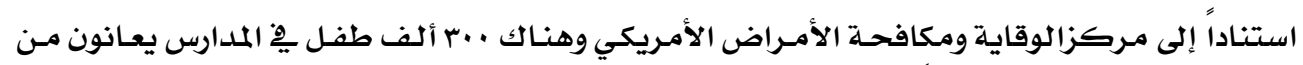

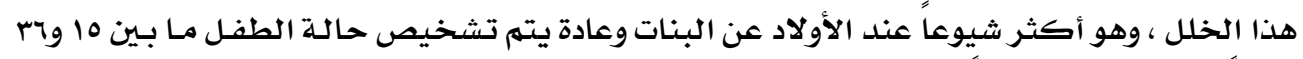

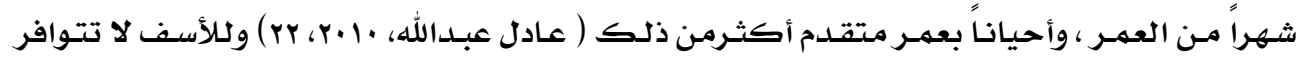

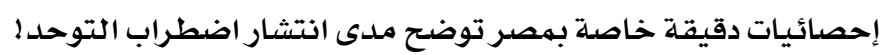
ويخ عام بعوا م كتب الطبيب النفسي ليوكانر Leo Kanner مقالـة تصف أحسى عشر

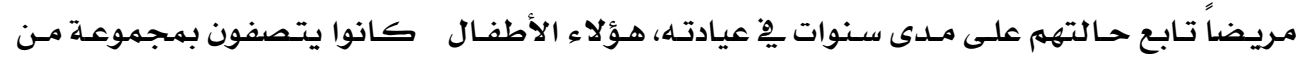

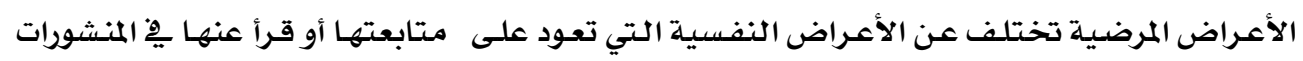

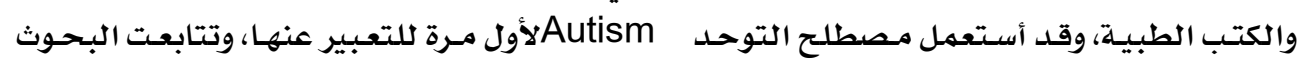

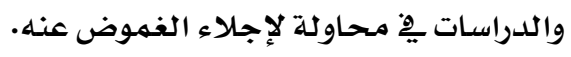
واضطراب التوحد يظل مصاحباً للطفل طوال حياته ، فهو خلل وظيفي يِ الجهاز العصبي

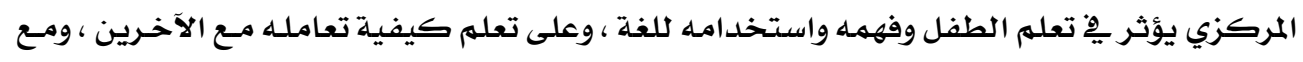

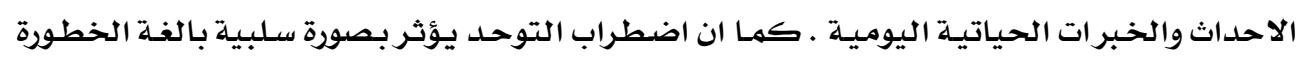

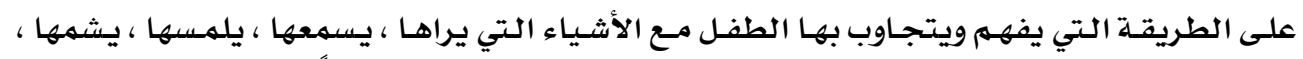

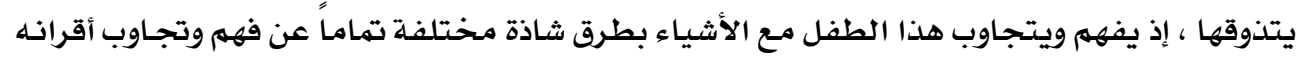

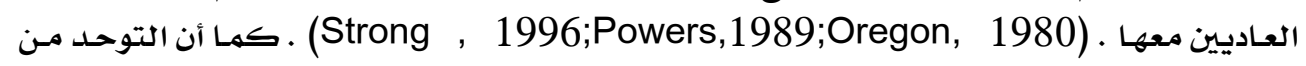

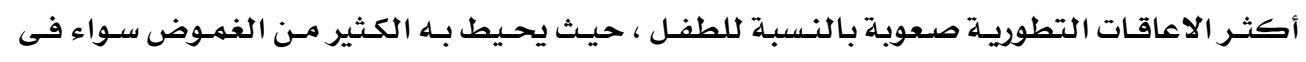

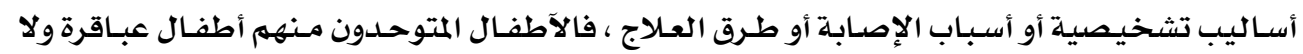

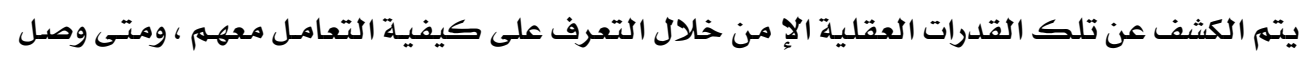
المحيطين بـه إلى مفتاح التعامل معهد ، نجد الطفل ينطلـق انطلاقة رهيبـا مهـا يفجـر القدرات الموجـودة

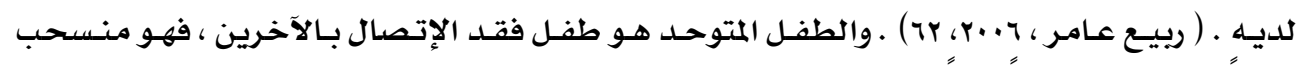

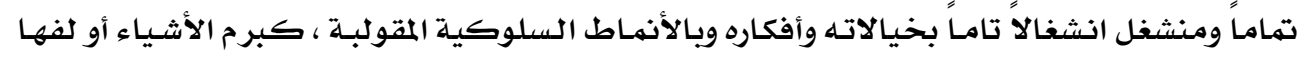
والهزهزة ولا مبالاته إزاء الوالدين والآخرين وعجزه عن تحمل التغيير إلى جانب عيوب النطق ، وتظل وهاهل

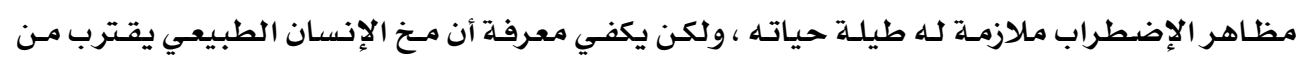

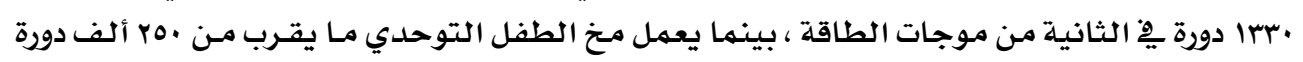

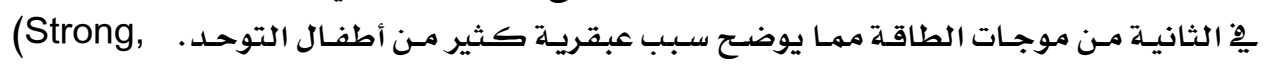
1996;Powers ,1989;Oregon ,1980)

وقد أثار التوحد العديد من التسـاؤلات والاستفسـارات منذ اكتشافه منذ خمسين عاماً حتى

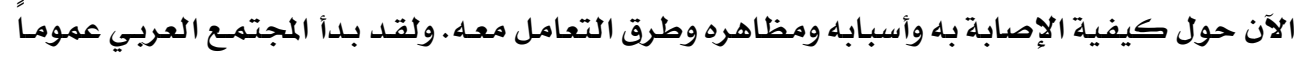


بالاهتمام بـه من خلال المقـالات الصحفية والنـدوات التعريفيـة ، وإن كان لا زال يفتقـر إلى المزيـد مـن

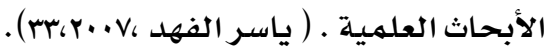

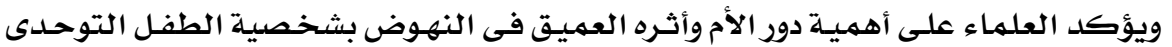

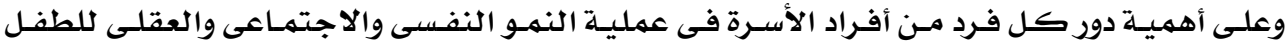

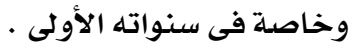

وعلى الرغم من أن شخصية كل مـن الوالدين والتفـاعلات بينهمـا وسـلوكهما نحـو الطفل

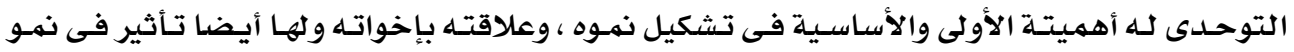

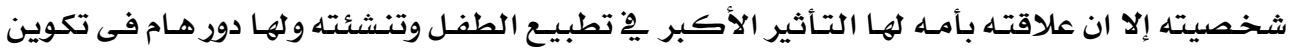

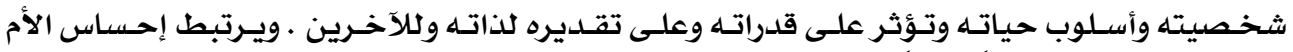

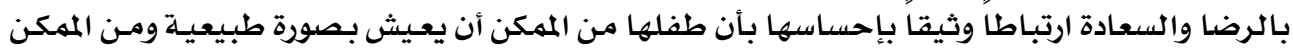

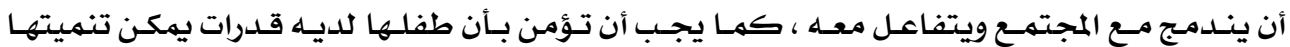

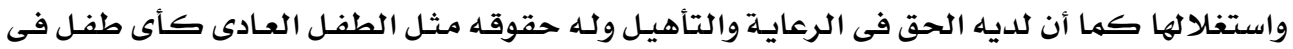

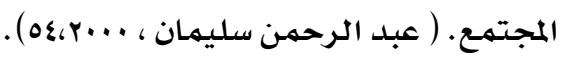

و من هنا يمكن القول أن هنالك بعض الأمور التي تفرض على الأسـرة ظروفا خاصـة ، ويمكن

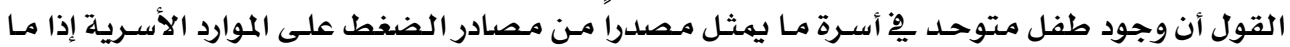

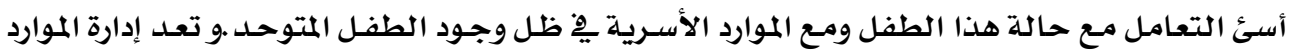

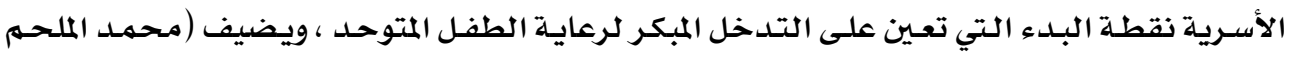

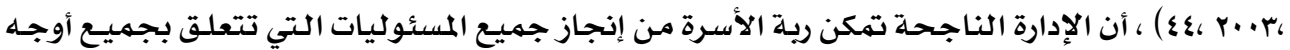

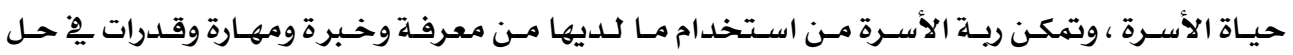

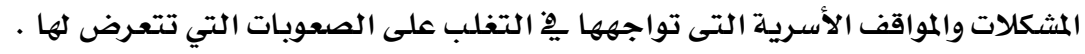
ومن خلال ما تقدم يهكن صياغة مشكلة الدراسـة يِّ التساؤل الرئيسي التالي: ما علاقة إدارة الموارد الأسرية لأم الطفل المتوحد ببعض المتغيرات الإجتماعية والإقتصاديةي

$$
\text { و يندرج من هذا التساؤل عدة تساؤلات فرعية وهي: }
$$

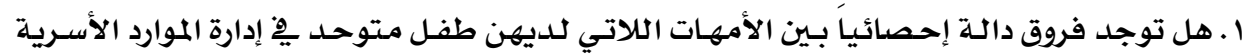

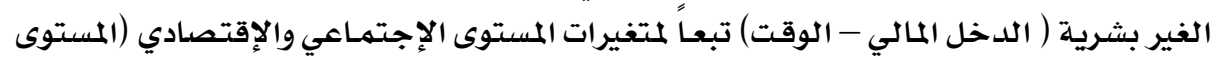

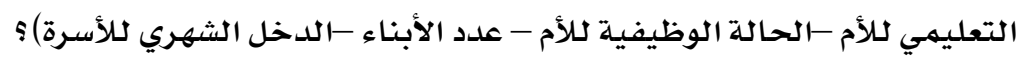

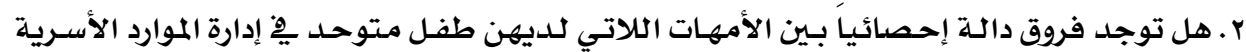

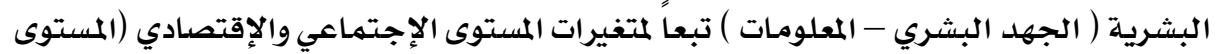

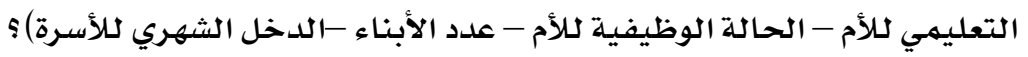




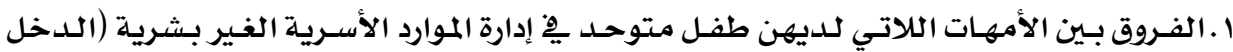

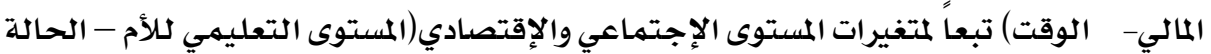

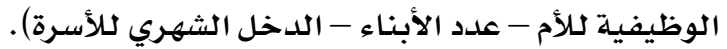

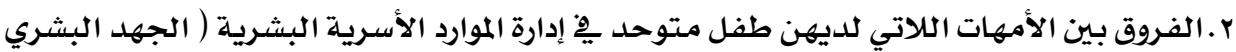

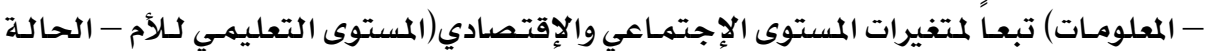

$$
\text { الوظيفية للأم - عدد الأبناء - الدخل الديرات المهري الإجتهاعي ولأسرة). }
$$

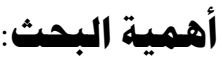

ا. إمـداد المكتبـات بمـرجـع عن إدارة الموارد الأسـريـة لأم الطفل المتوحسد وهو مـا تفتقر إليـه المكتبـات

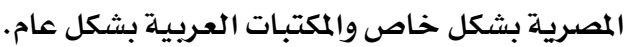

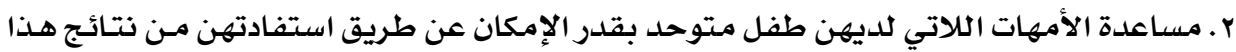
البحث ِِّ إدارة مواردهن الأسريـة.

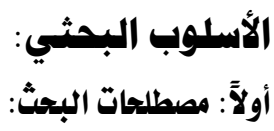

• إدارة المـوارد الأسـرية لأم الطفل المتوحسل: FAMILY RESOURCES MANAGEMENT FOR AUTISTIC CHILD'S MOTHER

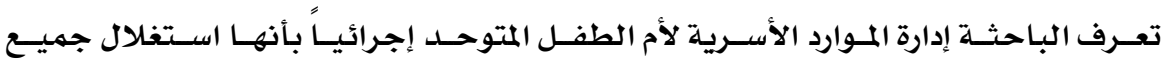

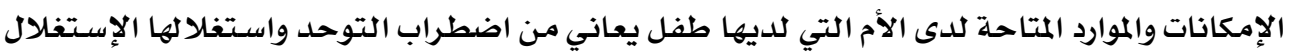

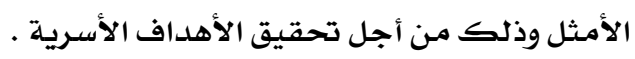
• إدارة مورد الدخل المالي : MONEY MANAGEMENT الامل تحقيق الاهل

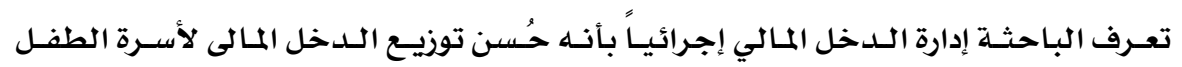

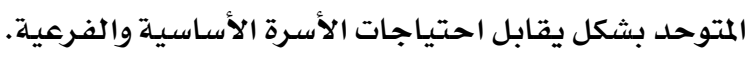
• إدارة مورد الوقت: TIME MANAGEMENT تعرف الباحثة إدارة الوقت إجرائياً بأنها حُسـن استخدامسه بفاعليه وكفـاءة تعهود على أسـرة

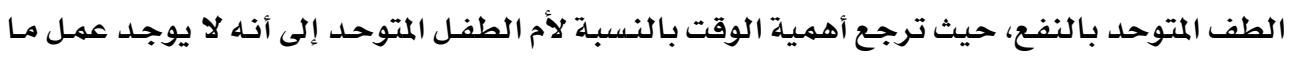

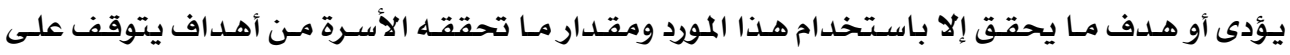

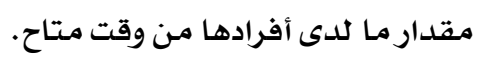
• إدارة الجهد البشري: HUMEN ENERGY MANAGEMENT تعرف الباحثة إدارة مورد الجهد البشري إجرائياً بأنه مساعدة أم الطفل المتوحد على أداء مـا

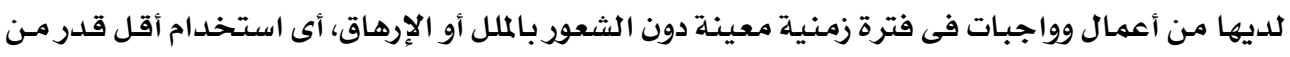
الطاقة فى تحقيق أكبر قدر من الأهداف الأسرية. 
INFORMATION MANAGEMENT : إدارة المعلومات

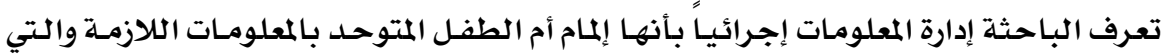

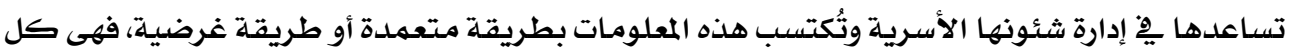

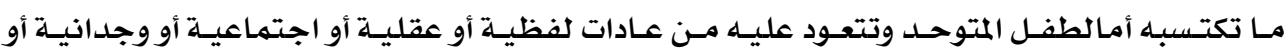

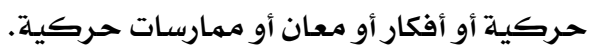
• التوحد:AUTISM

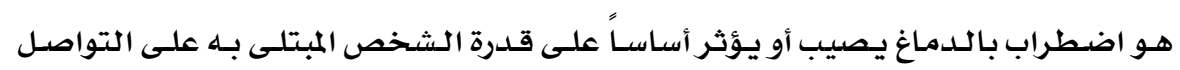

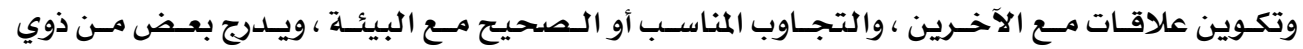

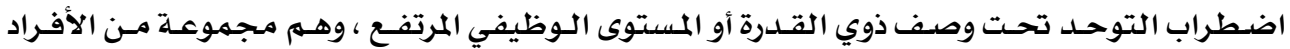

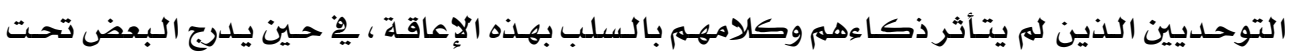

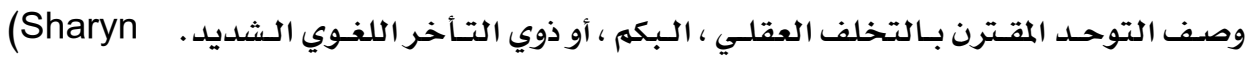
Neuwirth , 1997)

\section{ثانياً: فروض البحث:}

ا ـ توجد فروق ذات دلالة إحصائية بين الأمهات الكلاتي لديهن طفل متوحسد يِّ إدارة الموارد الأسـرية

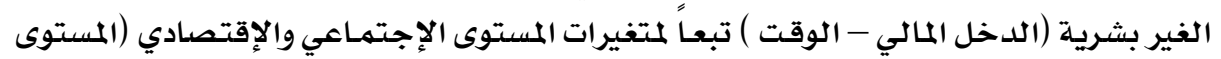

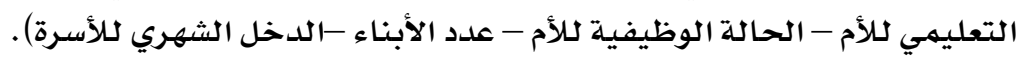

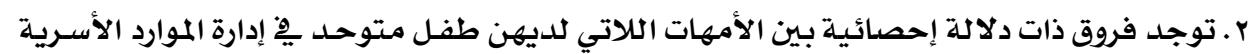

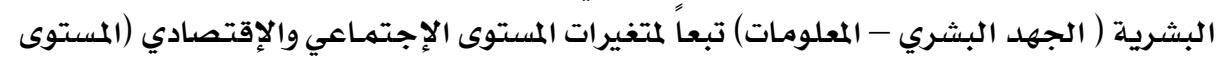

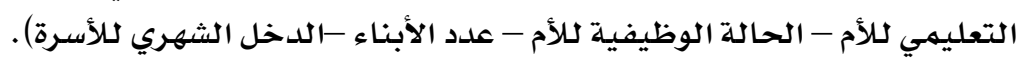

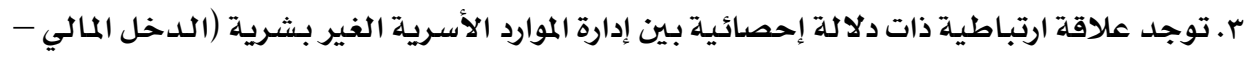

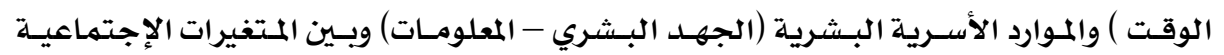

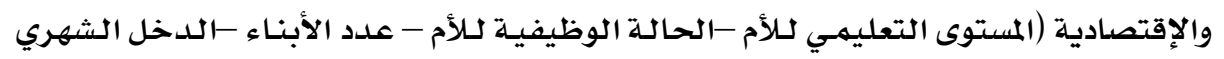
كلأسترة ). ع ـ تختلف نسبـة مشاركة العوامل المؤثرة على إدارةالموارد الأسرية.

ثالثاً: منهج البحث: يتبع هذا البحث المنهج الوصفي التحليلي.

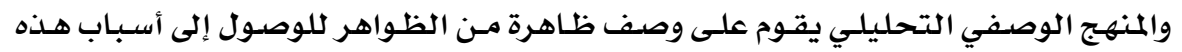

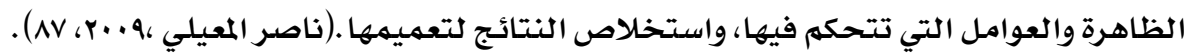




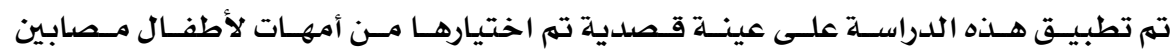

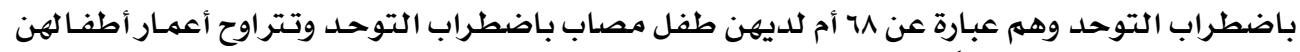

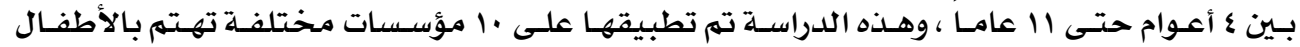

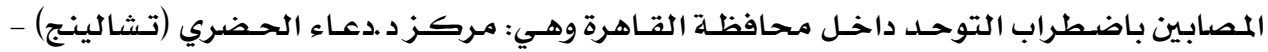

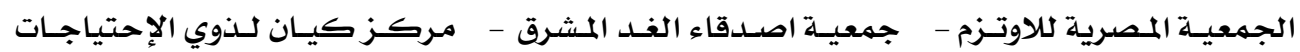

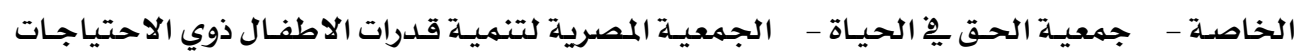

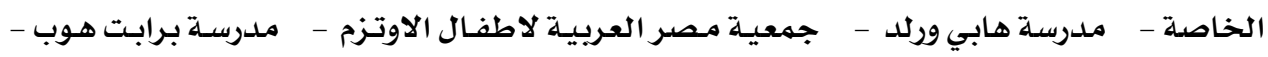

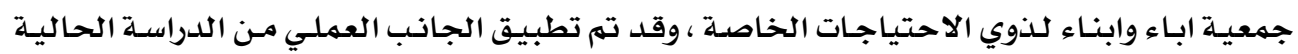

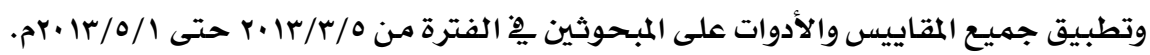

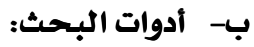
قامت الباحثة بإعداد الأدوات التالية:

1) استمارة المتغيرات الإقتصادية والإجتماعية.

وتهـف إلى التعرف على ( المستوى التعليمي لكلأم - الحالة الوظيفيـة لـلأم - عدد الأبناءمقدار الدخل الشهري).

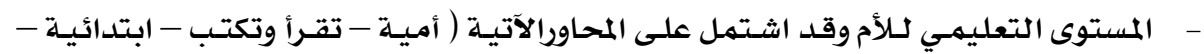

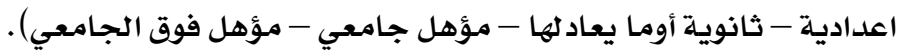

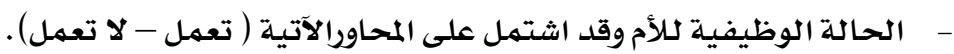

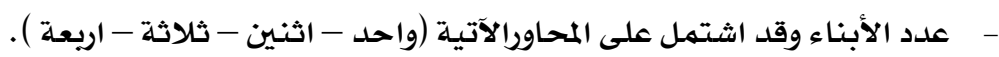

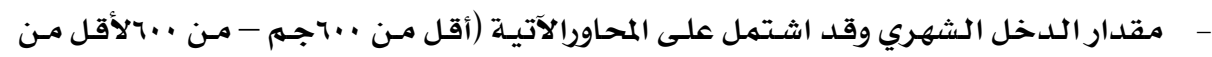

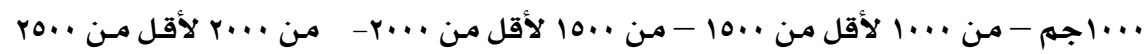

$$
\text { . }
$$

\section{r r مقياس إدارة الأم للموارد الأسرية الغير بشرية}

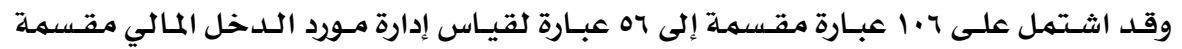

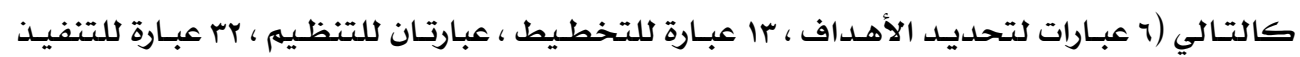

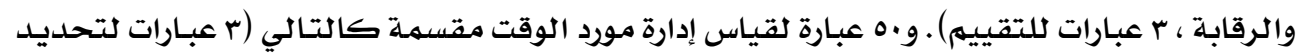

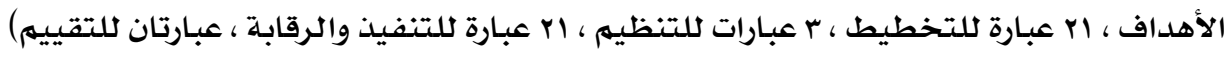

\section{r) مقياس إدارة الأم للموارد الأسرية البشرية أبارية}

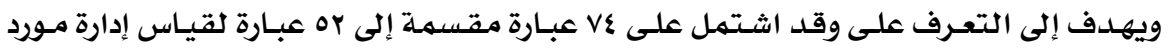

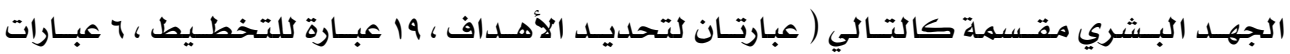




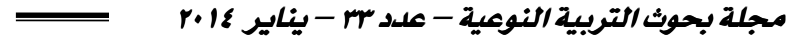

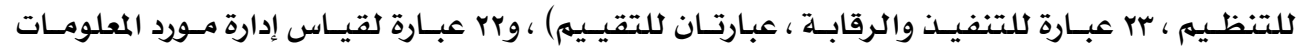

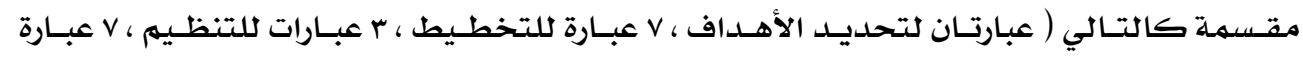

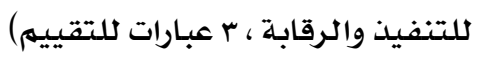

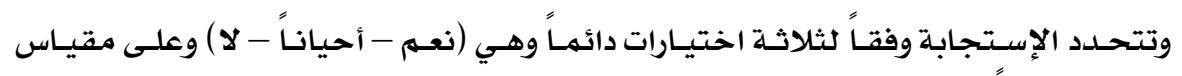

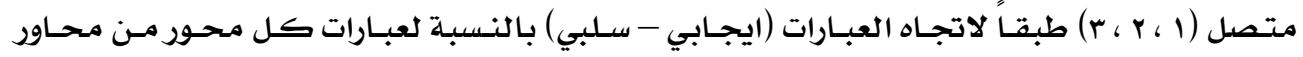

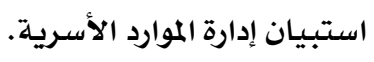
صدق المقياسان: - (1) تم حسـاب صدق المقياسان (الموارد الأسرية غير البشرية والموارد الأسـرية البشرية )باستخدلام

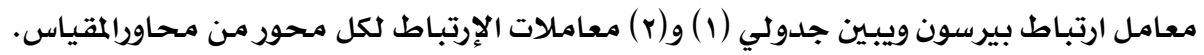

\begin{tabular}{|c|c|c|}
\hline الدلالة & الارتباط & \\
\hline$\cdot, \cdot 1$ & $\cdot, \mathrm{vr} \varepsilon$ & المحور الأول : مورد الدخل المالي للأسـرة \\
\hline$\cdot, \cdot 1$ & $\cdot, 107$ & المحور الثانى : إدارة مورد الوقت \\
\hline$\cdot, \cdot 1$ & $\cdot \wedge \varepsilon \wedge$ & الموارد الأسرية غير البشرية ككل \\
\hline
\end{tabular}

جدول (r) معاملات الإرتباط لكل محور والدرجة الكلية لمقياس إدارة الموارد البشرية

\begin{tabular}{|c|c|c|}
\hline الدلالة & الارتباط & \\
\hline$\cdot, \cdot 1$ & $\cdot$ • VIr & المححور الأول : الجهد البشري \\
\hline$\cdot, \cdot 1$ & •,人T\& & المحور الثاني : إدارة مورد المعلومـات \\
\hline$\cdot, \cdot 1$ & •,VYI & الموارد الأسريـة البشريـة ككل \\
\hline
\end{tabular}

يتضح من الجدولين ( ) ، (Y) أن معاملات الإرتباط كلها دالة عند مستوى 0.01 مها يـدل على صدق وتجانس عبارات المقياسان ثبات المقاييس: تم التحقق من ثبات مقاييس إدارة الموارد الأسرية الغير بشرية (الدخل المالي - الوقت) وإدارة

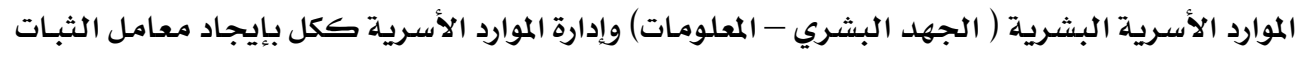

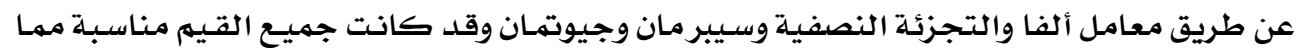

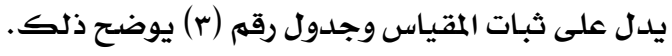


جدول (r) قيهم معامل الثبات لمقياسي الموارد الغيربشرية والبشرية والأسرية ككل

\begin{tabular}{|c|c|c|c|c|}
\hline جيوتمان & سبيرمان براون & التجزئة النصفية & معامل الفا & المحاور \\
\hline$\cdot, \wedge 71$ & $\cdot, 9.1$ & $\cdot, \wedge \leqslant 7$ & $\cdot, \wedge \vee \varepsilon$ & ثبات مقياس إدارة الموارد الأسرية غير البشرية \\
\hline$\cdot, \mathrm{V} \leqslant \mathrm{r}$ & $\cdot$, YAI & •, VYY & $\cdot, \mathrm{YOA}$ & ثبات مقياس إدارة الموارد الأسرية البشرية \\
\hline$\cdot, \lambda \cdot \wedge$ & $\cdot, \wedge \leqslant \cdot$ & $\cdot$, YAo & $\cdot, \wedge 17$ & ثبات مقياس إدارة الموارد الأسرية ككل \\
\hline
\end{tabular}

المعالجة الإحصائية:

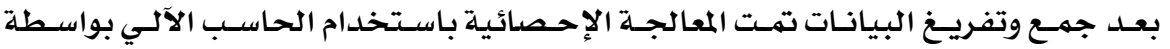

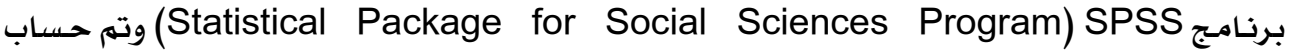

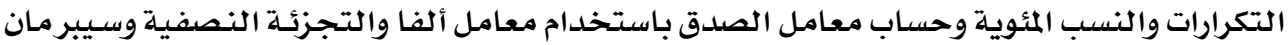

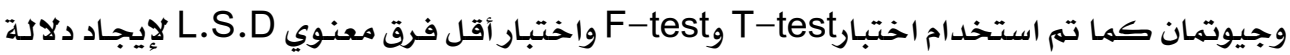

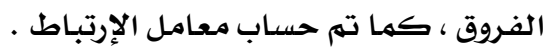

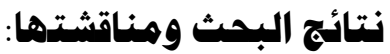
أولاً: توصيف عينة البحث:

جدول ( ) توزيع أفراد عينة البحث تبعاً للمستوى التعليمي للأم

\begin{tabular}{|c|c|c|}
\hline النسبـة ٪ & العدد & المستوى التعليمى للأم \\
\hline 25 & IV & منخفض \\
\hline 29.4 & $r$. & متوسط \\
\hline 45.6 & r & عالى \\
\hline 100 & $\pi$ & المجموع \\
\hline
\end{tabular}

جدول (ه) توزيـع أفراد العينـة تبعا للحالة الوظيفية للأم

\begin{tabular}{|c|c|c|}
\hline النسبـة ٪ & العدد الع & الححالة الوظيفيـة لـلأم \\
\hline 64.7 & $\varepsilon \varepsilon$ & تعمل \\
\hline 35.3 & rE & لا تعمل \\
\hline 100 & 71 & المجموع \\
\hline
\end{tabular}

جدول (؟) توزيـع أفراد العينـة تبعاً لعدد الأبناء

\begin{tabular}{|c|c|c|}
\hline النسبسية ٪ & العدد & عدد الأبناء \\
\hline 38.2 & YT & $r-1$ \\
\hline 42.6 & rq & r \\
\hline 19.2 & ir & $\varepsilon$ \\
\hline 100 & 71 & المجموع \\
\hline
\end{tabular}




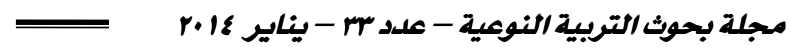

جدول (v) توزيع أفراد العينة تبعا لمتغير الدخل الثهري

\begin{tabular}{|c|c|c|}
\hline النسبة ٪ & العدد & الدخل الشهري \\
\hline 26.5 & 11 & منخفض \\
\hline 27.9 & 19 & متوسط \\
\hline 45.6 & r & مـرتفع \\
\hline 100 & 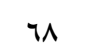 & المجموع \\
\hline
\end{tabular}

ثانياً: تتائج البحث في ضوءالفروض:

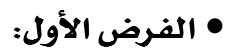

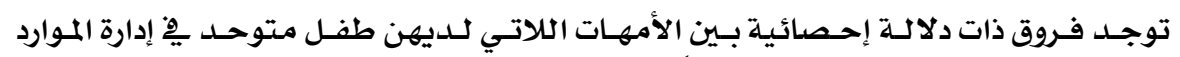

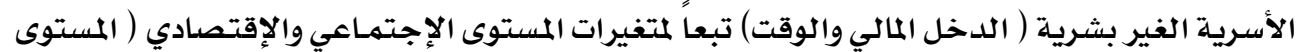

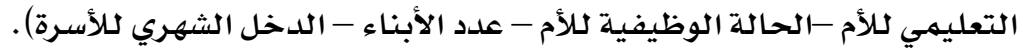

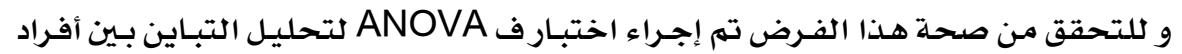

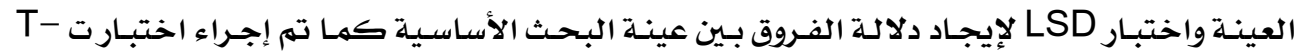

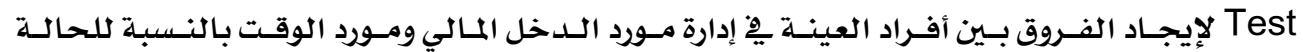

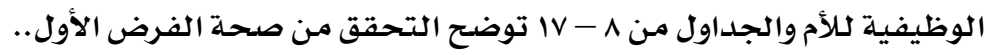
جدول (^) تحليل التباين بين أفراد العينة يِّ محاور مقياس إدارة الموارد الأسرية الغير بشرية (الدخل المالي -

\begin{tabular}{|c|c|c|c|c|c|c|}
\hline الدلالة & قيمة ف & درجات الحرية & متوسط المربعات & مجموع المربعات & مصدرالتباين & المحور \\
\hline \multirow{3}{*}{ دال عند 0.01} & \multirow[t]{3}{*}{46.791} & 2 & 11717.335 & 23434.670 & بين المجموعات & \multirow{3}{*}{ للداخل } \\
\hline & & 65 & 250.419 & 16277.216 & داخل المجموعات & \\
\hline & & 67 & - & 39711.885 & المجموع الكلي & \\
\hline \multirow{3}{*}{ دال عند 0.01} & \multirow[t]{3}{*}{43.596} & 2 & 10487.510 & 20975.020 & بين المجموعات & \multirow{3}{*}{ لوقت } \\
\hline & & 65 & 240.559 & 15636.334 & داخل المجموعات & \\
\hline & & 67 & & 36611.354 & المجموع الكلي & \\
\hline
\end{tabular}

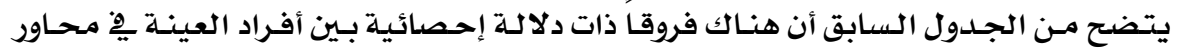

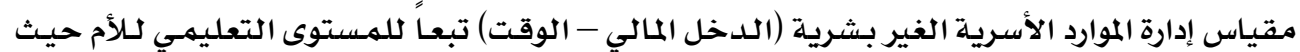

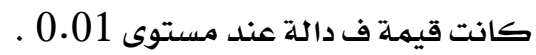
و لمعرفة اتجاه هذه الفروق لصالح مستوى التعليم (مسنخفض - متوسط - عالي) تم إجراء

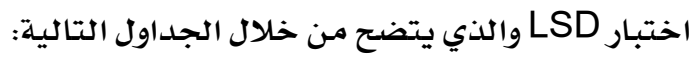


جدول (ه) دلالة الفروق بين إدارة مورد الدخل المالي تبعاً لاختلاف مستوى تعليه الأم

\begin{tabular}{|c|c|c|c|c|}
\hline م = عالي 115.4503 & م = متوسط & م = منخفض & مستوى تعليم الأم & المحور \\
\hline & & - & منخفض & \multirow{3}{*}{$\begin{array}{cc}\overline{3} & \overline{3} \\
3 & 3 \\
3 & \overline{3}\end{array}$} \\
\hline & - & $* * 8.122$ & متوسط & \\
\hline - & $* * 33.922$ & $* * 42.044$ & عالي & \\
\hline
\end{tabular}

يتضـح من الجـدول السـابق وجـود فـروق دالـة إحصـائيا عنـد إدارة مـورد الـدخل المالي بالنسبسة لمستوى تعلـيهم الأم ( مسنخفض - متتوسط - عالي) لصالح المستوى العـالي عند مسستوى دلالـة 0.01 وبين المستوى ( منخفضض- متوسط ) لصسالح المستوى المتوسط عند مستوى دلادة 0.01 . جدول ( • 1) دلالدة الفروق بين إدارة مورد الوقت تبعاً لاختلاف مستوى تعليم الأم

\begin{tabular}{|c|c|c|c|c|}
\hline 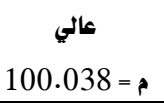 & متوسط = مت & م = منغفض & مستوى تعليم الأم & المحور \\
\hline & & - & منخفض & \multirow{3}{*}{ إدارة مورد } \\
\hline & - & $* * 7.486$ & متوسط & \\
\hline- & $* * 30.417$ & $* * 37.903$ & عالي & \\
\hline
\end{tabular}

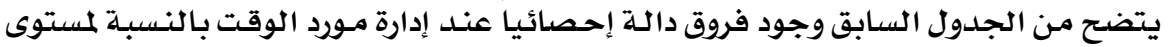
تعلـيهم الأم ( مـنخفض - متوسـط - عـالي) لـصالح المستوى العـالي عنـد مسستوى دلادهة 0.01 وبـين المستوى ( منـخفض- متوسط ) لصالح المستوى المتوسط عند مستوى دلالة 0.01 . و ترىى البـاحثة أنه مـن الجـداول ^ ،ه ، • أن محسوري إدارة الـدخل المالي وإدارة الوقت دال عنــ

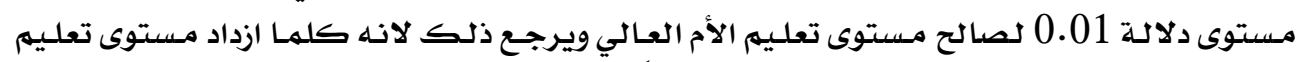
الأم كلما كان لديها اطلاع وإدراتك علٍ لقيمة كلاً مـن المال والوقت. جلدول (11) الفروق بين متوسط درجات إدارة الموارد الأسرية الغير بشرية ( الدخل المالي والوقت) تبعاً للحالة

\begin{tabular}{|c|c|c|c|c|c|c|c|}
\hline الدلالة & قيعة ت & |درجات الحرية & j & الإنحراف المعياري & المتوسط الحسابي & المتفير & المورد \\
\hline \multirow{2}{*}{ 01 0.01 لصالح العاملات عند } & \multirow[b]{2}{*}{8.463} & \multirow[b]{2}{*}{66} & 44 & 19.860 & 108.001 & تعمل & \multirow{2}{*}{ الدخل المالي } \\
\hline & & & 24 & 10.564 & 71.058 & لا تعمل & \\
\hline \multirow{2}{*}{ |دال عند 0101ثصالح غير } & \multirow[b]{2}{*}{12.950} & \multirow[b]{2}{*}{66} & 44 & 8.66534 & 67.1370 & تعمل & \multirow[t]{2}{*}{ الوقت } \\
\hline & & & 24 & 17.51751 & 108.1625 & لا تعمل & \\
\hline
\end{tabular}


من الجدول السابق يتضـح أن هناك فروقاً ذات دلالـة إحصائية بـين عمل الأم عند إدارة مـورد

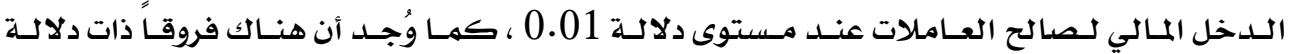

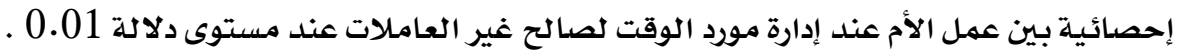

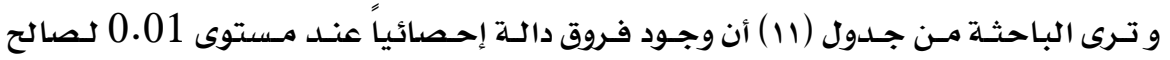

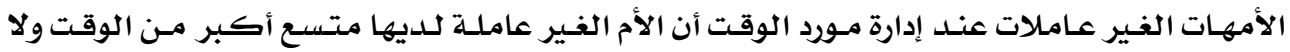

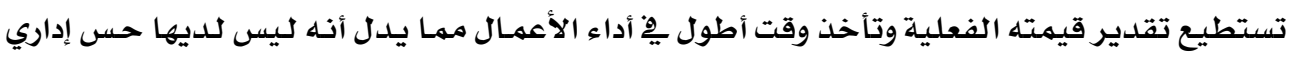

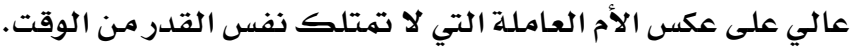

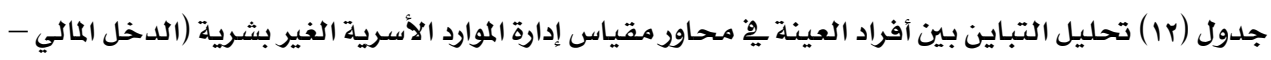

\begin{tabular}{|c|c|c|c|c|c|c|}
\hline الدلالة & قيمة ف & درجات الحرية & متوسط المربعات & مجموع المربعات & مصدرالتباين & المحور \\
\hline \multirow{3}{*}{ عند } & \multirow[t]{3}{*}{49.271} & 2 & 12341.932 & 24683.864 & بين المجموعات & \multirow{3}{*}{ المالي } \\
\hline & & 65 & 250.489 & 16281.769 & داخل المجموعات & \\
\hline & & 67 & - & 40965.633 & المجموع الكلي & \\
\hline \multirow{3}{*}{ عند } & \multirow[t]{3}{*}{22.584} & 2 & 15336.411 & 30672.822 & بين المجموعات & \multirow{3}{*}{ الوقت } \\
\hline & & 65 & 679.074 & 44139.831 & داخل المجموعات & \\
\hline & & 67 & - & 74812.654 & المجموع الكلي & \\
\hline
\end{tabular}

يتضـح مـن الجـدول السـابق أن هنـالك فروقـاً ذات دلالـة إحصائية بـين أفراد العينـة ِِّ محساور

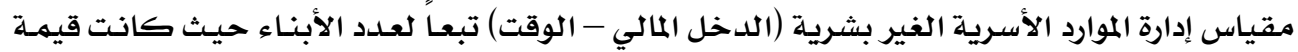

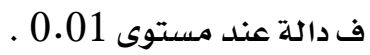
و لمعرفة اتجاه هذه الفروق تم إجراء اختبار LSD والذي يتضح من خلال الجداول التالية: جدول (rا ) دلادة الفروق بين إدارة مورد الدخل المالي تبعاً لاختلاف عدد الأبناء

\begin{tabular}{|c|c|c|c|c|}
\hline $\begin{array}{c}\varepsilon \\
74.1308=\text { ? }\end{array}$ & $\begin{array}{c}r \\
83.133=\text { ? }\end{array}$ & $\begin{array}{c}\text { r-I } \\
118.570=\text { ? }\end{array}$ & عدد الأبناء & المحور \\
\hline & & - & $r_{-1}$ & إدارة مورد \\
\hline & - & $* * 35.436$ & $r$ & اللدخل \\
\hline- & $* * 9.003$ & $* * 44.440$ & $\xi$ & المالي \\
\hline
\end{tabular}

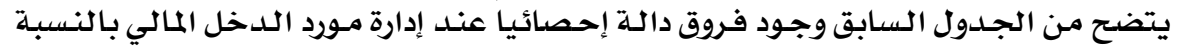

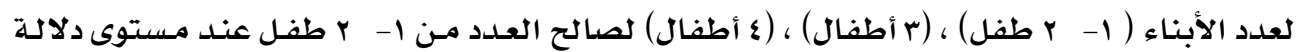

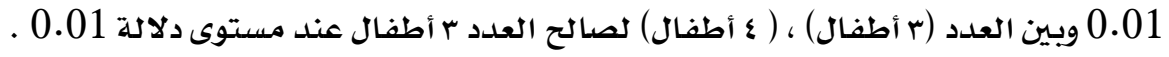


جدول (ع ا ) دلالة الفروق بين إدارة مورد الوقت تبعاً لاختلاف عدد الأبناء

\begin{tabular}{|c|c|c|c|c|}
\hline $\begin{array}{c}\varepsilon \\
60.715=\text { م }\end{array}$ & $\begin{array}{c}r \\
85.835=r\end{array}$ & $\begin{array}{c}r-1 \\
87.361=\end{array}$ & عدد الأبناء & المحور \\
\hline & & - & $r-1$ & \multirow{3}{*}{ إدارة مورد } \\
\hline & - & 1.526 & $r$ & \\
\hline - & $* 25.120$ & $* * 26.646$ & $\varepsilon$ & \\
\hline
\end{tabular}

يتضح من الجدول السابق وجود فروق غير دالة إحصائيا عند إدارة مورد الوقت بالنسبة لعدد إندا

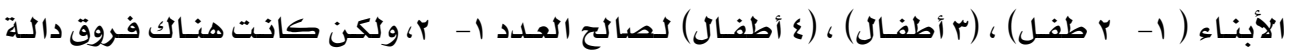

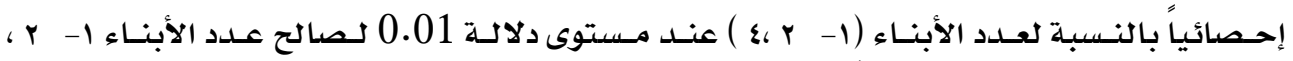

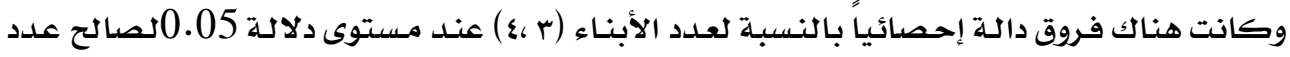
الأبناء باءت هناك.

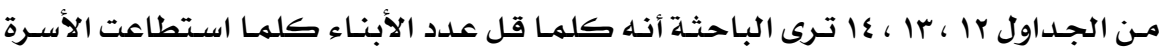

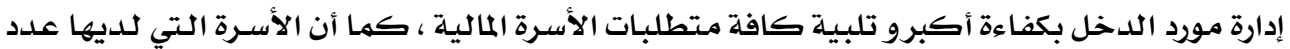

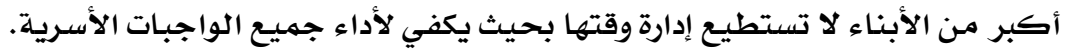

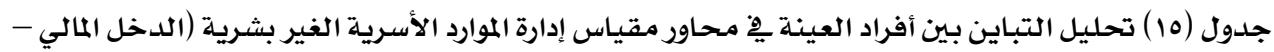

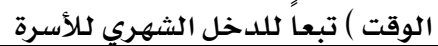

\begin{tabular}{|c|c|c|c|c|c|c|}
\hline الدلالة & قيمة ف & درجات الحرية & متوسط المربعات & مجموع المربعات & مصدرالتباين & 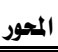 \\
\hline \multirow{3}{*}{ دال عند 0.01} & \multirow{3}{*}{$\begin{array}{c}52.3 \\
37\end{array}$} & 2 & 455191.371 & 910382.742 & بين المجموعات & \multirow{3}{*}{$\begin{array}{l}\overline{3} \\
\text { 夏 }\end{array}$} \\
\hline & & 65 & 8697.333 & 565326.636 & داخل المجموعات & \\
\hline & & 67 & - & 1475709.378 & المجموع الكلي & \\
\hline \multirow{3}{*}{ دال عند 0.01} & \multirow{3}{*}{$\begin{array}{c}30.4 \\
38\end{array}$} & 2 & 18903.145 & 37806.290 & بين المجموعات & \multirow{3}{*}{ 高 } \\
\hline & & 65 & 621.027 & 40366.787 & داخل المجموعات & \\
\hline & & 67 & - & 78173.077 & المجموع الكلي & \\
\hline
\end{tabular}

يتضـح مـن الجـدول السـابق أن هنـاك فروقاً ذات دلالـة إحصائية بـين أفراد العينـة يِّ محساور

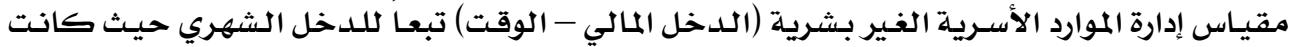

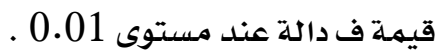
و لمعرفة اتجاه هذه الفروق تم إجراء اختبار LSD والذي يتضح من خلال الجداول التالية: 


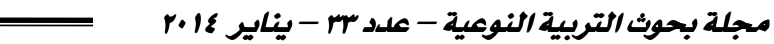

جدول (1 ) دلالة الفروق بين إدارة مورد الدخل المالي تبعاً لاختالاف مستوى الدخل الشهري

\begin{tabular}{|c|c|c|c|c|}
\hline م = مرتفع 115.4503 & متوسط = مت 81.9821 & م = منخفض & الدخل الشهري & المحور \\
\hline & & - & منخفض & \multirow{3}{*}{ إدارة مورد الدخل } \\
\hline & - & $* * 8.604$ & متوسط & \\
\hline- & $* * 33.468$ & $* * 42.072$ & مرتفع & \\
\hline
\end{tabular}

يتضح من الجـدول السـابق وجـود فروق دالـة إحصائيا عندل إدارة مـورد الدخل المالي بالنسبـة

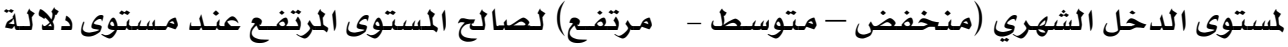

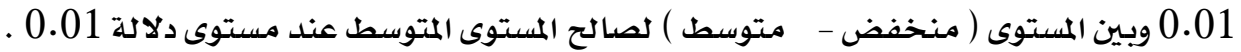
جدول (IV) دلالة الفروق بين إدارة مورد الوقت تبعاً لاختلاف مستوى الدخل الشهري

\begin{tabular}{|c|c|c|c|c|}
\hline م = مرتفع & متوسط = مت 86.752 & من = منخفض & الدخل الشهري & المحور \\
\hline & & - & منخفض & \multirow{3}{*}{ إدارة مورد } \\
\hline & - & $* 24.913$ & متوسط & \\
\hline - & $* * 3.199$ & $* * 28.113$ & مرتفع & \\
\hline
\end{tabular}

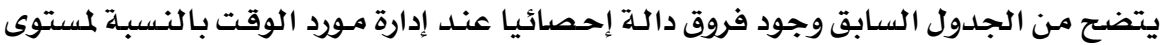

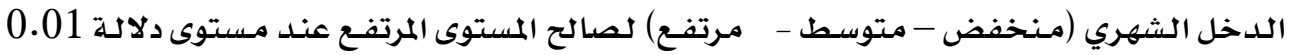

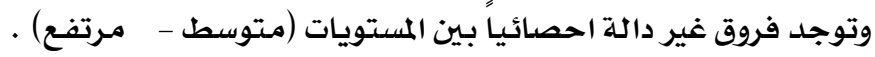

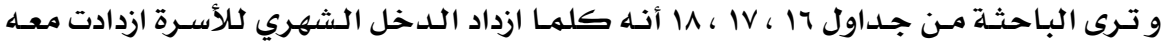

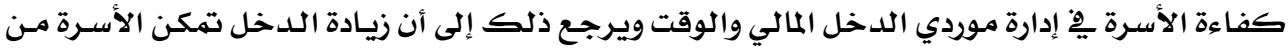

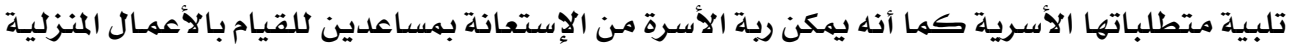

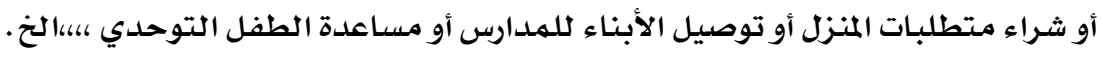

$$
\text { • (الفرض الثاني: }
$$

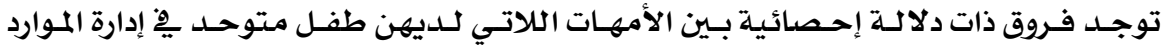

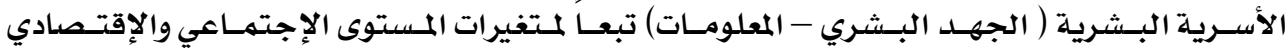

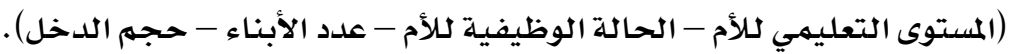

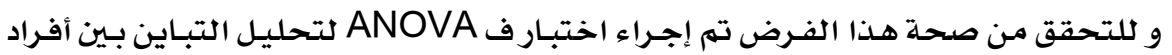

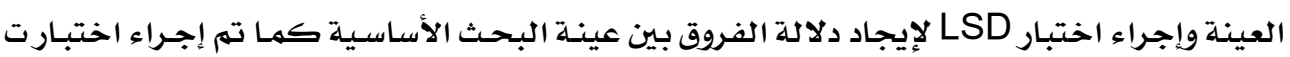
T-Test

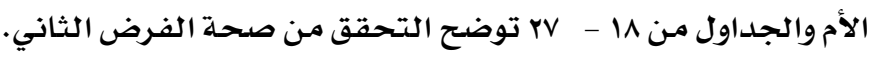




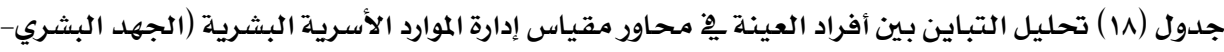

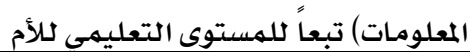

\begin{tabular}{|c|c|c|c|c|c|c|}
\hline الدلالة & قيمة ف & درجات الحرية & متوسط المربعات & مجموع المربعات & مصدرالتباين & المحور \\
\hline \multirow{3}{*}{ دال عند 0.01} & \multirow{3}{*}{38.986} & 2 & 5961.067 & 11922.133 & بين المجموعات & \multirow{3}{*}{ البشري } \\
\hline & & 65 & 152.903 & 9938.669 & داخل المجموعات & \\
\hline & & 67 & - & 21860.802 & المجموع الكلي & \\
\hline \multirow{3}{*}{ دال عند } & & 2 & 99250.595 & 198501.189 & بين المجموعات & \multirow{3}{*}{ لمعلومات } \\
\hline & & 65 & 2302.799 & 149681.963 & داخل المجموعات & \\
\hline & & 67 & - & 348183.152 & المجموع الكلي & \\
\hline
\end{tabular}

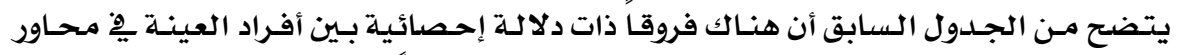

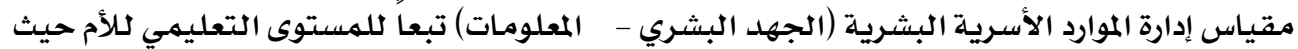

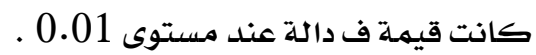

و لمعرفة اتجاه هذه الفروق لصالح مستوى التعليم (مسنخفض - متوسط - عالي) تم إجـراء

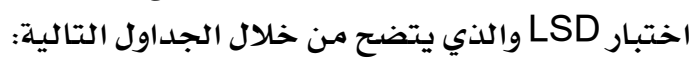
جدول (19) دلالة الفروق بين إدارة مورد الجهد البشري تبعاً لاختلاف المستوى التعليمي للأم

\begin{tabular}{|c|c|c|c|c|}
\hline م = عالي & مت = متوسط & م = منغفض & مستوى تعليم الأم & المحور \\
\hline & & - & منخفض & \multirow{3}{*}{ إدارة مورد } \\
\hline & - & 3.460 & متوسط & \\
\hline - & $* * 26.790$ & $* * 30.250$ & عالي & \\
\hline
\end{tabular}

يتضح من الجدول السابق وجود فروق دالة إحصائياً عند إدارة مورد الجهد البشري بالنسبة البـا

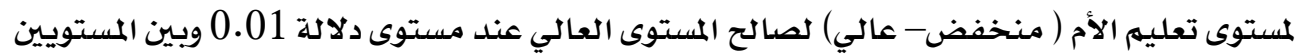

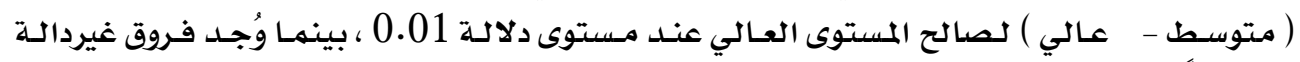

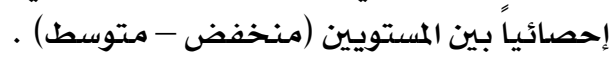

جدول ( • ) دلالة الفروق بين إدارة مورد المعلومات تبعاً لاختلاف مستوى تعليم الأم

\begin{tabular}{|c|c|c|c|c|}
\hline 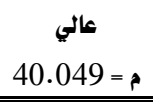 & $\begin{array}{c}\text { متوسط = م } 30.258 \\
30\end{array}$ & 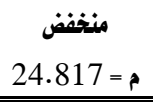 & مستوى تعليم الأم & المحور \\
\hline & & - & منخفض & \multirow{3}{*}{ إلمارة مورد } \\
\hline & - & $* * 5.441$ & متوسط & \\
\hline - & **9.791 & $* * 15.232$ & عالي & \\
\hline
\end{tabular}




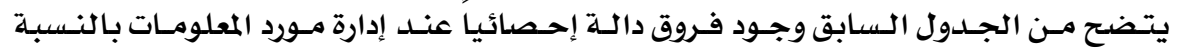

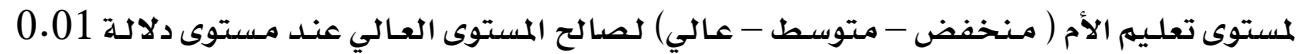

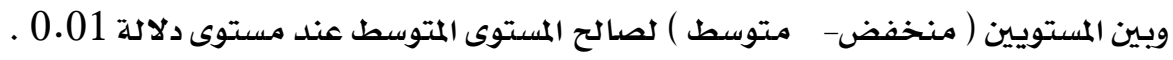

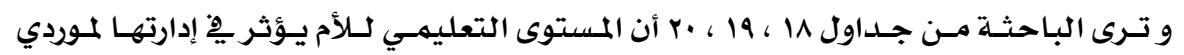

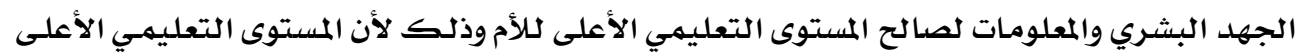

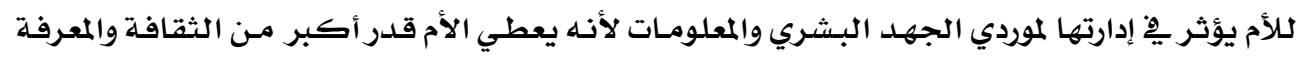

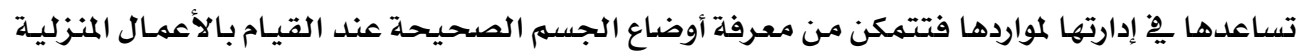

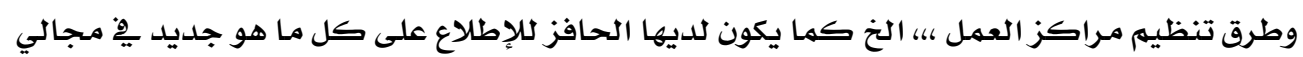
إدارة الموارد والتوحد وأي مجالات أخرىى. جدول (rا إل الفروق بين متوسط درجات إدارة الموارد الأسرية البشرية (الجهد البشري والمعلومات) تبعاً للحالة

\begin{tabular}{|c|c|c|c|c|c|c|c|}
\hline الدلالة & قيهة ت & درجات الحرية & j & الإنحراف المعياري & المتوسط الحسابي & المتفير & المورد \\
\hline \multirow{2}{*}{ دال عند 0.01 نصالح } & \multirow[b]{2}{*}{11.428} & \multirow[b]{2}{*}{66} & 44 & 11.214 & 67.978 & تعمل & \multirow{2}{*}{ الجهلد البشري } \\
\hline & & & 24 & 4.965 & 95.571 & لا تعمل & \\
\hline \multirow{2}{*}{ دال عند 0.010لصالح } & \multirow[b]{2}{*}{9.656} & \multirow[b]{2}{*}{66} & 44 & 11.986 & 37.450 & تعمل & \multirow[t]{2}{*}{ المعلومات } \\
\hline & & & 24 & 1.979 & 25.865 & لا تعمل & \\
\hline
\end{tabular}

من الجدول السابق يتضـح أن هناك فروقاً ذات دلالـة إحصائية بـين عمل الأم عند إدارة مـورد

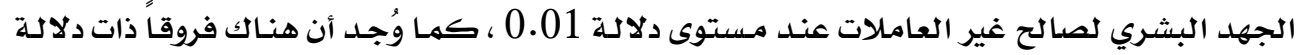

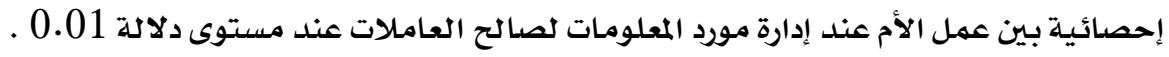

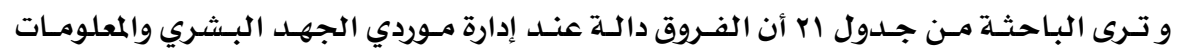

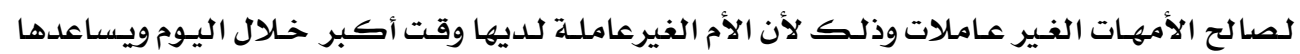

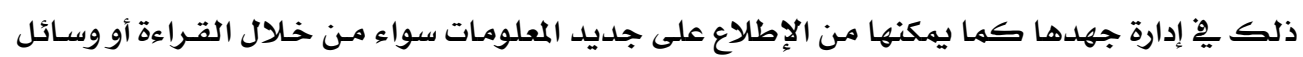
الإعلام المختلفة. جدول (rr) تحليل التباين بين أفراد العينة يِّ محاور مقياس إدارة الموارد الأسرية البشرية (الجهد البشري المعلومات ) تبعاً لعدد الأبناء

\begin{tabular}{|c|c|c|c|c|c|c|}
\hline الدلالة & قيمة ف & درجات الحرية & متوسط المربعات & مجموع المربعات & مصدرالتباين & المحور \\
\hline \multirow{3}{*}{ دال عند } & \multirow[t]{3}{*}{32.487} & 2 & 11946.280 & 23892.559 & بين المجموعات & \multirow{3}{*}{ الجهد البشري } \\
\hline & & 65 & 367.721 & 23901.846 & داخل المجموعات & \\
\hline & & 67 & - & 47794.406 & المجموع الكلي & \\
\hline \multirow{3}{*}{ دال عند } & \multirow[t]{3}{*}{42.918} & 2 & 50961.855 & 101923.710 & بين المجموعات & \multirow[t]{3}{*}{ المعلومات } \\
\hline & & 65 & 1187.411 & 77181.742 & داخل المجموعات & \\
\hline & & 67 & - & 179105.453 & المجموع الكلي & \\
\hline
\end{tabular}




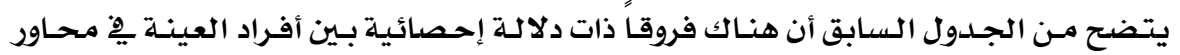

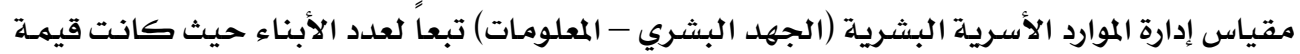
ف دالة عند مستوى 0.01 . و لمعرفة اتجاه هذه الفروق تم إجراء اختبار LSD والذي يتضح من خلال الجداول التالية:

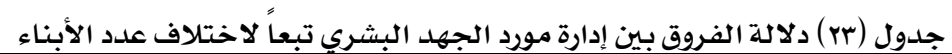

\begin{tabular}{|c|c|c|c|c|}
\hline $\begin{array}{c}\varepsilon \\
58.372=\text { ค }\end{array}$ & $\begin{array}{c}r \\
80.442=\text { P }\end{array}$ & $\begin{array}{c}r-1 \\
84.350=\text { ? }\end{array}$ & عدد الأبناء & المحور \\
\hline & & - & $r_{-1}$ & \multirow{3}{*}{ إدارة مورد الجهد } \\
\hline & - & 3.907 & $r$ & \\
\hline- & $* * 22.070$ & $* * 25.978$ & $\varepsilon$ & \\
\hline
\end{tabular}

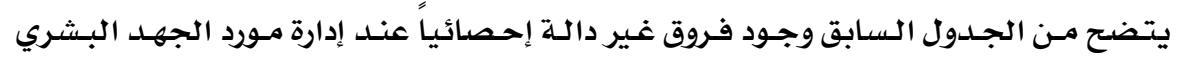

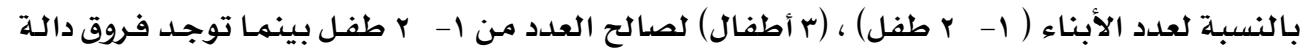

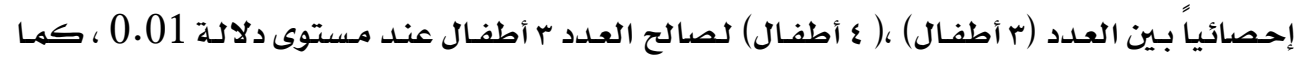

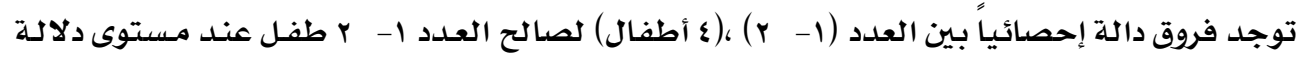
0.01

جدول ( ع ) دلالة الفروق بين إدارة مورد المعلومات تبعاً لاختالاف عدد الأبناء

\begin{tabular}{|c|c|c|c|c|}
\hline $\begin{array}{c}\varepsilon \\
24.663=\text { ? }\end{array}$ & $\begin{array}{c}r \\
29.738=\text { A }\end{array}$ & $\begin{array}{c}r_{-1} \\
41.752=\text { ? }\end{array}$ & علد الأبناء & المحور \\
\hline & & - & $r_{-1}$ & \multirow{3}{*}{ إلمارة مورد } \\
\hline & - & $* * 12.013$ & $r$ & \\
\hline- & $* * 5.075$ & $* * 17.089$ & $\xi$ & \\
\hline
\end{tabular}

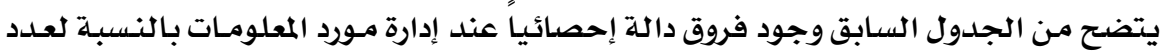

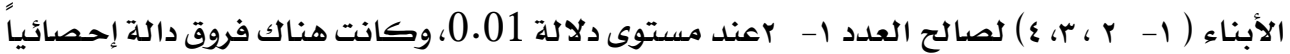

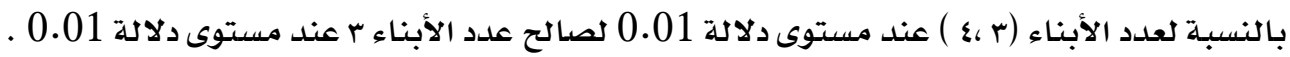

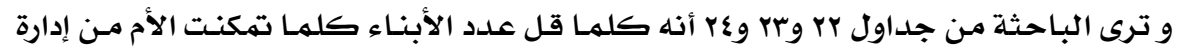

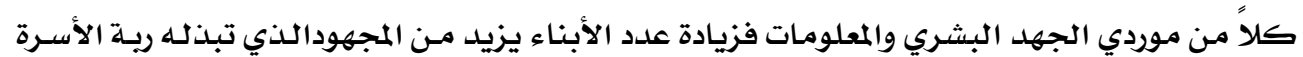

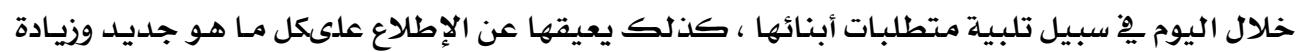
معلوماتها وإثرائها. 
مجلة بحوث التربية النوعية - علدد بr - بيناير

جدول (ro) تحليل التباين بين أفراد العينة ِِّ محاور مقياس إدارة الموارد الأسرية البشرية ( الجهد البشري -

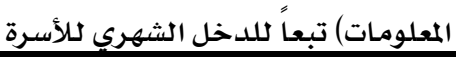

\begin{tabular}{|c|c|c|c|c|c|c|}
\hline الدلالة & قيمة ف & درجات الحرية & متوسط المربعات & مجموع المربعات & مصدرالتباين & المحور \\
\hline \multirow{3}{*}{ دال عند } & \multirow[t]{3}{*}{46.687} & 2 & 5340.230 & 10680.461 & بين المجموعات & \multirow{3}{*}{ البشري } \\
\hline & & 65 & 114.384 & 7434.944 & داخل المجموعات & \\
\hline & & 67 & - & 18115.405 & المجموع الكلي & \\
\hline \multirow{3}{*}{ دال عند } & \multirow[t]{3}{*}{55.365} & 2 & 58972.195 & 117944.391 & بين المجموعات & \multirow[t]{3}{*}{ المعلومات } \\
\hline & & 65 & 1065.156 & 69235.149 & داخل المجموعات & \\
\hline & & 67 & - & 187179.540 & المجموع الكلي & \\
\hline
\end{tabular}

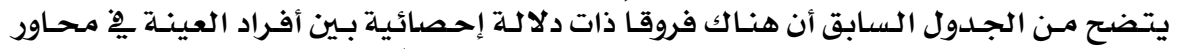

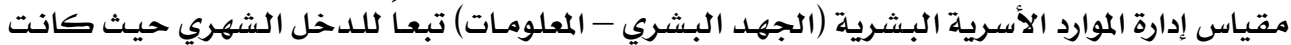
قيمة ف دالة عند مستوى 0.01 .

و لمعرفة اتجاه هذه الفروق تم إجراء اختبار LSD والذي يتضـح من خلال الجداول التالية:

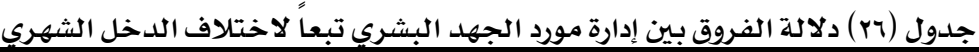

\begin{tabular}{|c|c|c|c|c|}
\hline م = مرتفع & م = متوسط & م م = منفضض & الدخل الشهري & المحور \\
\hline & & - & منخفض & إدارة مورد \\
\hline & - & $* * 14.178$ & متوسط & الجهل \\
\hline- & **18.518 & $* * 32.697$ & مرتفع & البشري \\
\hline
\end{tabular}

يتضـح من الجدول السابق وجود فروق دالة إحصائيا عند إدارة مورد الجهد البشري بالنسبـة

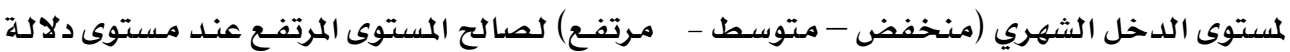

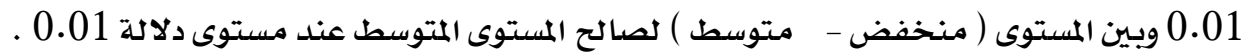

جدول (rV) دلالة الفروق بين إدارة مورد المعلومات تبعاً لاختلاف مستوى الدخل الشهري

\begin{tabular}{|c|c|c|c|c|}
\hline م = مرتفع & م = متوسط & م = منخفض & الدخل الشهري & المحور \\
\hline & & - & منخفض & \multirow{3}{*}{ إلمارة مورد } \\
\hline & - & $* * 4.259$ & متوسط & \\
\hline - & $* * 12.722$ & $* * 16.981$ & مرتفع & \\
\hline
\end{tabular}

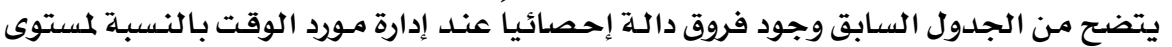

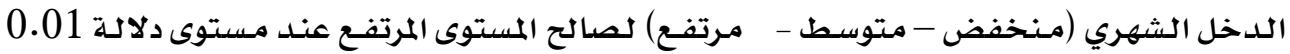




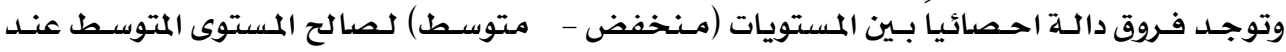
مستوى دلالة 0.01 0. 0.

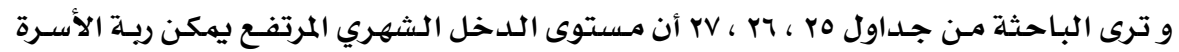

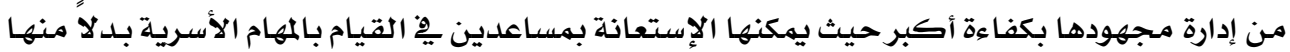

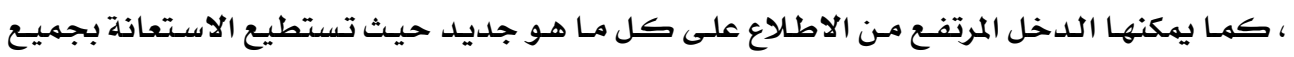

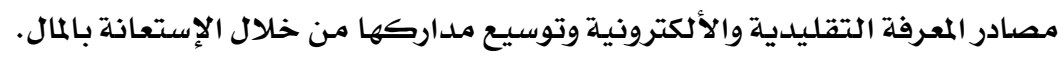

$$
\text { • الفرض الثالث: }
$$

توجد علاقة ارتباطية ذات دلالة إحصائية بين إدارة الموارد الأسرية الغير بشرية (الدخل المالي

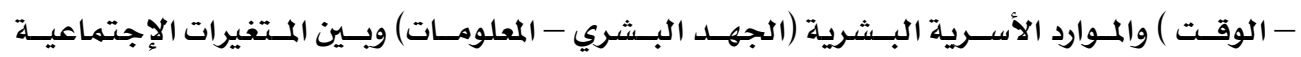

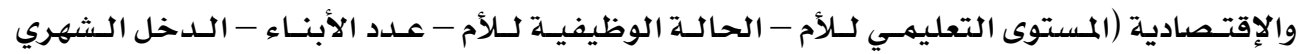
كلأسـرة).

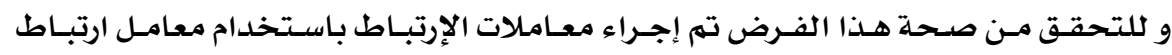

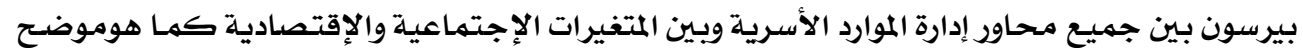

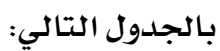

جدول (rی) معامل الإرتباط بين إدارة الموارد الأسرية ومتغيرات المستوى الإجتماعي والإقتصادي للأسرة

\begin{tabular}{|c|c|c|c|c|c|c|c|}
\hline إلأسرة الموارد & |إدارة الموارد الأسرية & إدارة مورد & الجهد البشري & |إدارة الموارد الأسرية غير & إدارة مورد الوقت & مورد اللدخل المالي & \\
\hline$* * . \wedge \vee$. & $* * . \wedge r q$ & $* * .94$ & $* * . \vee \vee 91$ & $* *, \wedge \leq 7$ & $* . .7 \leq Y$ & ***.人 • & المستوى التعليمي للأم \\
\hline. $.1 \mathrm{rV}$ & .101 &.$r \cdot r$ & .118 & $.11 r$ & $\because 1 \leq \leq$ & $.1 \cdot 1$ & الحالة الوظيفية للأم \\
\hline$* * . \vee \vee \wedge \bullet$ & $* .7 .1=$ & $* . . T Y r$. & $* * \cdot .9 .9=$ & $* * . \wedge \neg r=$ & $* * . V Y_{1}=$ & $* *, \Lambda \cdot r=$ & عدد أفراد الأسرة \\
\hline$* * ., \vee \circ \leq$ & $* * \cdot \wedge \cdot \Lambda$ & *. . Y & $* * . \wedge 17$ & $* * . \wedge 91$ & $* * .91 \leq$ & $* * . \vee Y Y \uparrow$ & اللدخل الشهري للأسرة \\
\hline
\end{tabular}

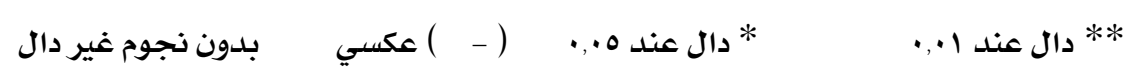

$$
\text { يتضح من الجدول السـابق ما يلي: }
$$

•وجـود علاقــة ارتبـاطيـة موجبـة بــين المستوى التعليمـي لـلأم وكـل مـن إدارة مـورد الـدخل والموارد

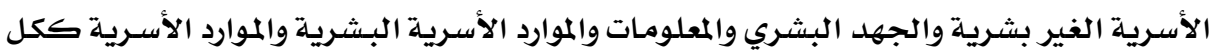

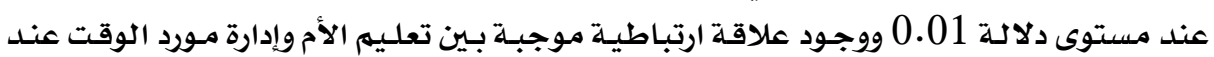

$$
\text { مستوى دلالة 0.05. }
$$

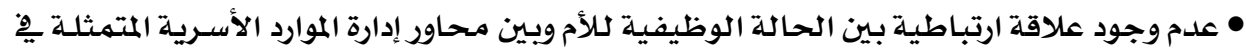

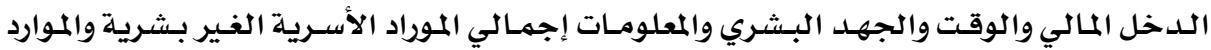

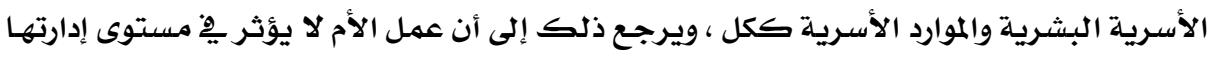

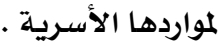




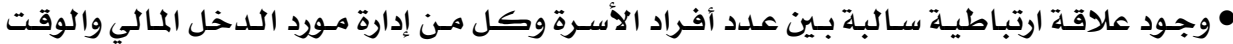

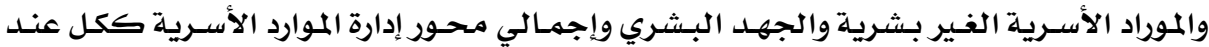

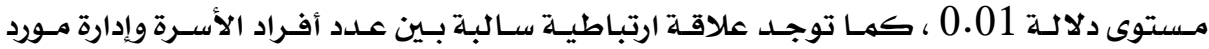

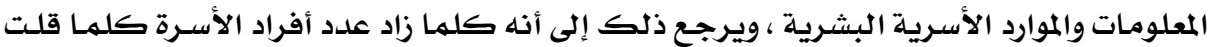
قدرة ريـة الأسرة على إدارة مورادها الأسريية بكفاءة.

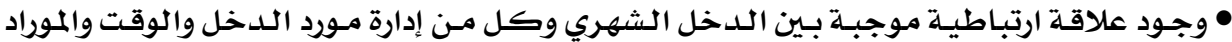

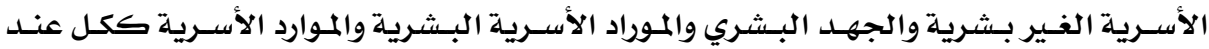

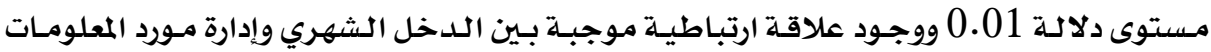
عند مستوى دلالة 0.05 مستوى دلادة

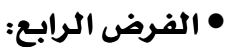
تختلف نسبة مشاركة العوامل المؤثرة على إدارة الموارد الأسريـة.

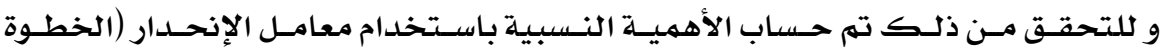

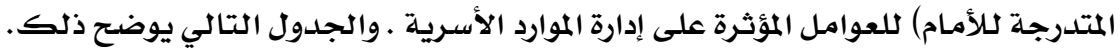
جدول (وץ) الأهمية النسبية باستخدام معامل الانحدار (الخطوة المتدرجة إلى الأمام) للعوامل المؤثرة

\begin{tabular}{|c|c|c|c|c|c|c|c|c|}
\hline الدلالة & قيمة (ت) & معامل الانحدار & الدلالة & قيمة ف) & نسبة الشاركة & معامل الارتباط & التتفير الستقل & \multirow{4}{*}{ الإارة الموارد } \\
\hline$\bullet, \cdot 1$ & $9, r \varepsilon r$ & צ & ., & $\Delta V, r q$. & •, ror & $\cdot, A v$. & تعليي الأم & \\
\hline •, & r,or. & •,OrA & ., & $07,0 \leqslant 0$ & •, 779 & •,AIA & عمر الأم & \\
\hline$\cdot, \cdot 1$ & $7, \cdot \vee 7$ & ل & •, & $r q, q 1 r$ & $\cdot, 079$ & •, Y०\& & الدخل الشهري & \\
\hline
\end{tabular}

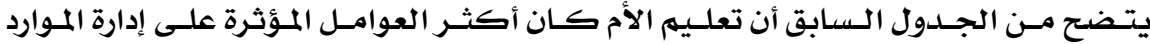

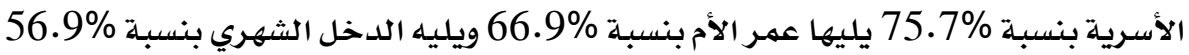

\section{توصيسات الدراسة:}

مِّْ ضوء نتائج الدراسة توصي الباحثة بالتالي: ا ـ اعداد وتصميهم برامـج ارشادية لأمهات أطفال التوحد توضـح لهن كيفية إدارة مواردهن الأسـرية

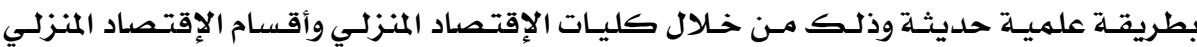

$$
\text { بكليات التربية النوعية. }
$$

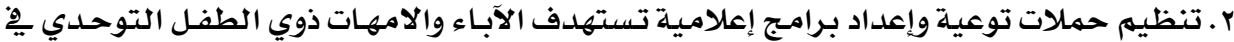

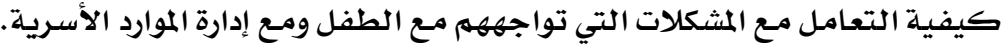

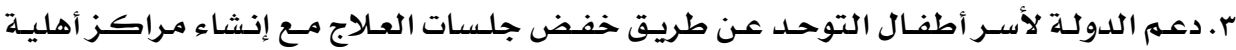

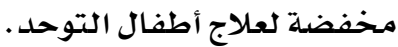




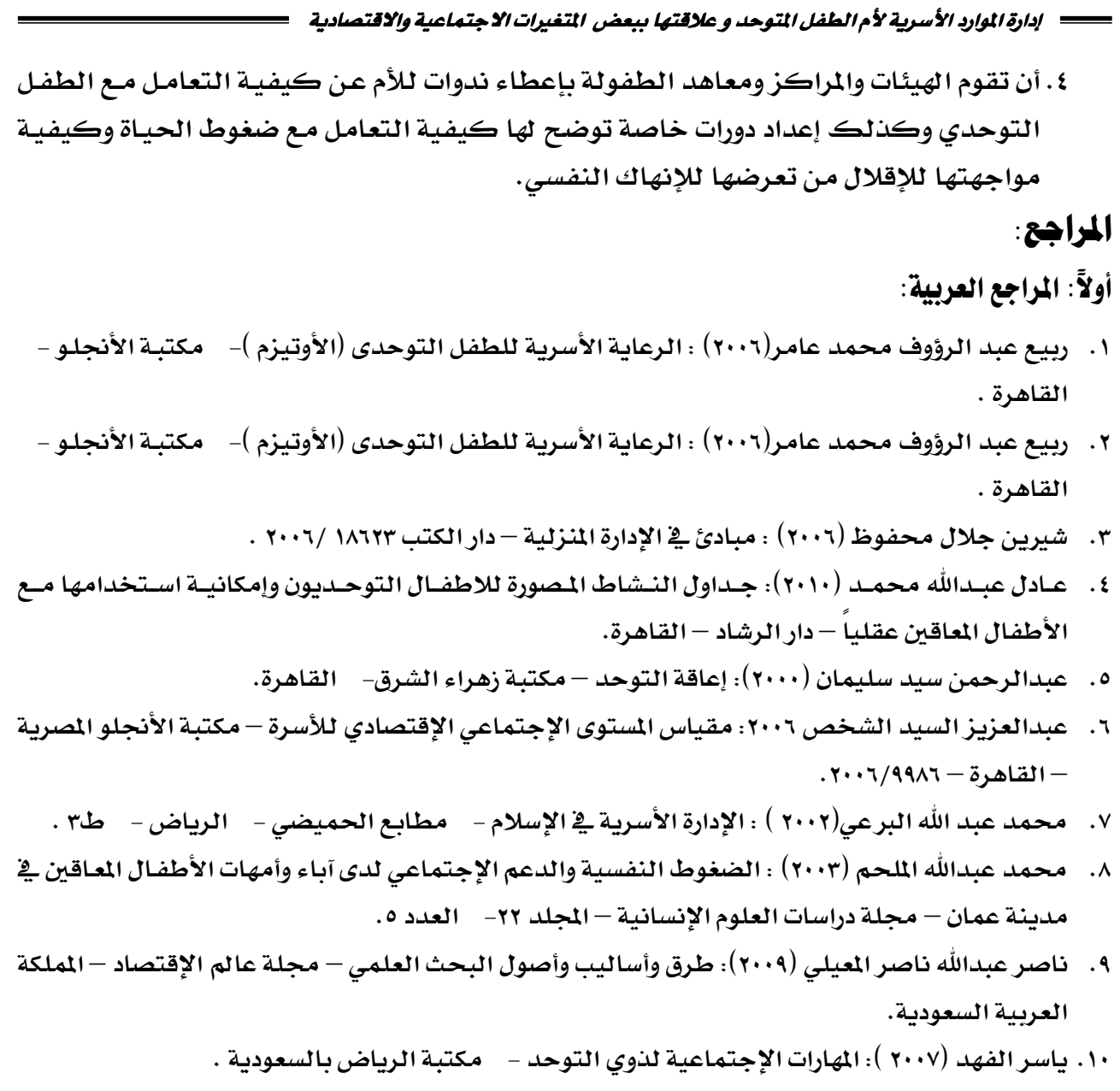

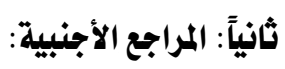

11.Strong, C. (1996):Autism: An Introduction for Parents and a Guide to Autism

12.Powers, M.D. (Ed.). (1989): Children with Autism: A Parents' Guide.Rockville, MD: Woodbine House.

13. Oregon's Service System (2nd ed.)(1980). Salem, OR: Autism Training Project/Oregon Technical Assistance Corporation.

14. Sharyn Neuwirth (1997): Autism , The National Institute of Mental Health Press , N: .4023- 97 